\title{
Integrating Library Research and Service: The Case of Internet Training for Small Business Executives
}

\section{Wen-Hua Ren and Ka-Neng Au}

\begin{abstract}
Library research and service have the potential to be complementary. This paper reports on how the desire to better serve small business users for their government information needs led to a research survey of small business executives in New Jersey and how the research findings provided further motivation, guidance, and input to a successful Internet training program. The authors' experiences show that academic librarians could improve effectiveness in both library research and service if they seek to integrate these two aspects of their career.
\end{abstract}

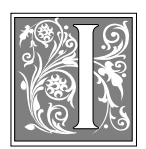

$n$ academic libraries, most tenure-track librarians have to balance their work in, or contributions to, librarianship, scholarship, and professional service in order to survive or thrive in the tenure system. Of the three components, scholarship, which generally involves research and publication, is frequently viewed as the most challenging for librarians. Previous research has shown that "the most frequent cause for librarians being denied tenure is an inadequate research and publication record." ${ }^{1}$ A rigid work schedule, insufficient research training, and the lack of research support and funding have been among the most frequently cited reasons. ${ }^{2}$

A review of the literature revealed two contrasting views among academic librarians regarding the relationship between a librarian's research and his or her library service. One is the separative view, which "separates professional practice from scholarship and service, and splinters what is designed to be a cohesive and complementary process." ${ }^{3}$ The librarians who hold this view regard scholarship as an additional burden, claiming that "a requirement or an expectation to perform research and to publish it could result in a serious reduction in the level of service provided to the library's users." ${ }^{4}$ This view of library research conflicting with library service was said to have contributed to the resentment toward, and difficulty in, library research and publication. ${ }^{5}$

An integrative view of research and library service has been presented to academic librarians as a positive alternative. This view projects benefits that research can bring to library service. For example, research is said to "facilitate concrete understanding of the access and service

Wen-Hua Ren is a Documents/Business Librarian in the John Cotton Dana Library at Rutgers, the State University of New Jersey; e-mail: whren@newark.rutgers.edu. Ka-Neng Au is a Business Librarian, also in the John Cotton Dana Library at Rutgers; e-mail: au@newark.rutgers.edu. The authors wish to extend their gratitude to the Center for Entrepreneurial Management at Rutgers University, the New Jersey Small Business Development Center, and the Rutgers University Libraries for their support. 
needs of the library clientele," ${ }^{\prime 6}$ and "helps librarians understand what they must do to best serve their users" due to the increasing rate of change in information technology. ${ }^{7}$ Furthermore, to be integrated into the librarian's work of service, research should be meaningful to the librarian in that it reflects and enhances his or her experience, education, and professional expertise. "Ideas for scholarly projects should come, at least to some extent, from the daily work of the librarian who is involved in planning and developing services and programs and in making decisions related to them." ${ }^{\prime 8}$

\section{In this paper, the authors report their efforts to create a synergy between research and service.}

In view of the requirements of the tenure system and the rapid change of information technology in the service environment of the academic librarian, the authors hold that the question is not whether academic librarians should integrate research and library service but, rather, how. Integration is critical not only for academic librarians to obtain career security and advancement, but also for the creation of knowledge and the improvement of quality for library service. In this paper, the authors report their efforts to create a synergy between research and service. Specifically, they describe how a research project on government information searching grew from service to the small business users and how research findings led to the successful creation and implementation of a training program for the small business community.

\section{Identifying the Government Information Needs of Small \\ Businesses}

The increased use of the Internet by the government for publishing and disseminating government information presents challenges as well as opportunities for small businesses. To run their businesses successfully, small business people need timely, accurate, and authoritative information, much of which is collected and published only by the federal government. Prior to the Internet, government publications had been published primarily in the print format and were available only in depository libraries. Whereas large companies had their information needs taken care of by in-house information specialists, small business users usually had to conduct information searches themselves with or without the assistance of government agencies and the depository libraries. The Internet now provides access to government-published information, and small business users can obtain this information anywhere and at any time.

However, the benefits of the Internet to the small business community depend on answers to many questions. For example, do the small business owners have computer and Internet access? Assuming they have access, what, if any, type of government information do they need? Are they aware that much government information is available on the Internet and free for access? Do they have the necessary skills to search for information on the Internet? Do they need some form of Internet training?

Answers to these questions are essential for providing high-quality service to the small business community, which is regarded as an important sector of the clientele of Rutgers University's John Cotton Dana Library. The Dana Library, which serves the Rutgers-Newark campus, has been a federal depository library since 1966. Government publications, especially in business and economics, are among the resources that librarians use most frequently in their daily reference services. With its large business collection and its librarian expertise in business and management information and government documents, the library has become an integral part of the entrepreneurship and small business development community in Newark. The campus is home to the state headquarters of the New Jersey Small Business Development Center 
(SBDC) as well as the Center for Entrepreneurial Management, a research center administered by the Rutgers Faculty of Management, which has been expanding its entrepreneurship studies. Due to all the aforementioned reasons, the library attracts many users from the surrounding community, including small business users.

In response to the growing government information needs by small businesses, a study was designed to survey small business executives in the state of New Jersey in summer 1997. Eighty-one executives participated. Major questions were asked about the need for and use of government information and the awareness of its availability on the Internet. Also included in the survey was a free training program about government information on the Internet to be offered to interested participants of the study.

The survey revealed that 87.2 percent of the respondents owned a computer and 73.1 percent had Internet access. Although 65.4 percent of the respondents rated government information important or somewhat important to their business operations, as many as 55.1 percent of the participants were unaware that government information is available on the Internet; even fewer $(27.2 \%)$ could list any government Internet sites they had visited. Most of the small business executives relied on secondary sources to obtain government information. Over 82 percent did not or infrequently consulted public consultants (depository librarians, SBDC consultants, and government officials) for government information retrieval and use. Many executives $(61.2 \%)$ had little confidence in their ability to search for electronic government information. Only 8.6 percent had some kind of training in government information searching, and 64.2 percent expressed a strong interest in learning how to search the Internet for government information.

These research findings provided very important input and impetus to the setting up of the Internet training program for the interested small business execu- tives. First, as government documents and business librarians, the authors' motivation was boosted by the findings that government information was important and the small business users needed Internet training. Second, the research findings earned the credibility to lobby for moral, administrative, and financial support. Finally, and most important, the data helped the authors design and conduct the training program, including determining the scope of the training, scheduling the program, and selecting training sources.

\section{Designing and Conducting the Internet Training Obtaining Program Support}

Research played a key role in obtaining the support and commitment from the various stakeholders. The application for funding was made on the basis of the research findings, and the fact that the research had been published further enhanced the authors' credibility. ${ }^{9}$ The training project gained strong support from the Center for Entrepreneurial Management at Rutgers, which funded the training program, and the SBDC, which sponsored the program and administered its publicity mailing and registration. The library administration allocated time for program design and training and provided electronic classrooms and other facilities. ${ }^{10}$

\section{Program Goals}

Based on the findings of the 1997 survey, the authors set up the following goals for the training program: (1) to increase awareness that the U.S. government publishes valuable information on the Internet by introducing the attendees to a variety of Internet government information sources; (2) to encourage and enable small business users to use governmentpublished information on the Internet by teaching them basic search skills and familiarizing them with various formats of the Internet government publications; (3) to increase their awareness of the types of assistance available to small business 
users (i.e., depository libraries in the community and librarians' expertise) so as to increase government information use and enhance the academic libraries' relationship with the small business community.

\section{All sessions were conducted in a library electronic classroom, where the instructor was able to post the live Internet demonstration onto individual computer screens and trainees were able to have hands-on practice during the training.}

\section{Training Schedule, Locations, and Facilities}

The survey responses showed that the most-preferred training time was a weekday morning. Accordingly, the training program was scheduled on Friday mornings. The program was repeated on three Rutgers campuses for the convenience of the participants: the Newark campus in the northern part of New Jersey, the New Brunswick campus in the central part of the state, and the Camden campus in the southern part of New Jersey. All sessions were conducted in a library electronic classroom, where the instructor was able to post the live Internet demonstration onto individual computer screens and trainees were able to have hands-on practice during the training.

\section{Training Topics}

As shown in the 1997 survey, government regulatory and legislative types of information were of greatest importance to small business operations; and business / market-related statistical information (market research, economic statistics, and demographic data) was the second most important. These findings were taken into account in designing the three-hour training program. The training topics were broken into two sections: "What is my market?" and "What is my environment?" The former covered areas of industry information, demographics and consumers, and economic and financial statistics; the latter included current regulations, pending and current legislation, and sources of assistance.

\section{Conducting the Training}

Attendees. Thirty-five small business users attended the training sessions. Based on the information from those who filled out the program evaluation, 60 percent of the trainees were male, 55.2 percent were black, and 46.7 percent were fortyfive to fifty-four years old, 60 percent had college degrees or some college education, and 33.3 percent had graduate degrees or some graduate education. About 59 percent of the trainees were owners, 7.4 percent were managers, and 22.2 percent were employees. Some small business owners were unable to attend but asked to be notified of future programs. Approximately 56 percent were from the service sector and about 40 percent had had their business for more than six years. Tables 1 and 2 present individual and business information on the attendees.

\begin{tabular}{|c|c|c|c|c|c|c|}
\hline \multicolumn{7}{|c|}{$\begin{array}{c}\text { TABLE } 1 \\
\text { Individual Background Information } \\
\end{array}$} \\
\hline $\begin{array}{l}\text { Age } \\
(n=30)\end{array}$ & $\%$ & $\begin{array}{l}\text { Gender } \% \\
(n=30)\end{array}$ & $\begin{array}{l}\text { Education } \\
(\mathrm{n}=\mathbf{3 0})\end{array}$ & $\%$ & $\begin{array}{l}\text { Ethnic Status } \\
(\mathrm{n}=29)\end{array}$ & $\%$ \\
\hline $15-24$ & 6.7 & Male & High school & 6.7 & Black & 55.2 \\
\hline $25-34$ & 6.6 & Female & Some college & 40.0 & White & 27.6 \\
\hline $35-44$ & 30.0 & & College degree & 20.0 & Asian/Pacific Islande & er 6.9 \\
\hline $45-54$ & 46.7 & & Some grad. school & 13.3 & Hispanic & 3.4 \\
\hline $55-64$ & 6.7 & & Graduate degree & 20.0 & American Indian & 3.4 \\
\hline 65-over & 3.3 & & & & Other & 3.4 \\
\hline
\end{tabular}


TABLE 2

Business Information

\begin{tabular}{lrlrlr}
$\begin{array}{l}\text { Position } \\
(\mathbf{n = 2 7 )}\end{array}$ & $\mathbf{\%}$ & $\begin{array}{l}\text { Years in Business } \\
(\mathbf{n}=\mathbf{3 1})\end{array}$ & $\mathbf{\%}$ & $\begin{array}{l}\text { Industry } \\
\mathbf{( n = 3 0 )}\end{array}$ & $\mathbf{\%}$ \\
\hline Owner & 59.3 & Under 1 & 12.9 & Service & 56.6 \\
Manager & 7.4 & $1-3$ & 19.4 & Construction & 16.7 \\
Employee & 22.2 & $4-6$ & 3.2 & Retail & 10.0 \\
Other & 11.1 & Above 6 & 38.7 & Wholesale & 6.7 \\
& & Planning phase/ & & Manufacturing & 3.3 \\
& & Not in business & 25.8 & Other & 6.7 \\
\end{tabular}

Training methods. All the topics and sources used in the training were presented in the form of a Web page, which served as the instruction outline, the hands-on practice guide, and the posttraining review guide. ${ }^{11}$ The trainees were shown the three to four most commonly used government sources for each topic area. Real business questions were used to introduce the sources as answers in order to stimulate interest in the audience. For example, under industry information in the "What is my market?" section, the question, How many bakeries are there in Camden County? was answered by a source link to the County Business Patterns (Census Bureau). After the presentation of each section, participants had hands-on practice in reviewing the demonstrated sources and exploring related new sites selected for practice. Librarians were available for assistance in the searching and for consultation with real business information questions. During the training, the participants also learned about the federal depository libraries, the small business development centers, and other programs where they could receive a variety of assistance.

\section{Assessing Training Effectiveness}

To examine the effectiveness of the training program, the trainees were asked to fill out two questionnaires, one before the training started and the other immediately after the training was completed.

\section{Pretraining Assessment}

The pretraining assessment provided data to be compared with data collected in the posttraining assessment. The pretraining assessment contained three categories: knowledge, Internet use, and confidence in Internet searching.

Knowledge. On a five-point scale (1 being very little and 5 being a lot), the trainees were asked to indicate the extent to which they knew that (1) the government will publish most of its information in electronic format, such as on the Web; (2) much government information can already be found on the Internet; and (3) special assistance in finding government information is available in federal depository libraries in their community.

Internet use frequency. On a five-point scale $(1=$ never, $2=$ rarely, $3=$ couple of times a month, $4=$ every week, and $5=$ every day), the trainees reported how frequently they searched for information on government and nongovernment Web sites.

Confidence. On a five-point scale with 1 being least confident and 5 being most confident, the trainees reported how confident they were in searching for government information on government Web sites and on nongovernment agency Web sites.

\section{Posttraining Assessment}

The posttraining assessment collected information on the usefulness of the training topics and the effect of the training on the trainees' knowledge of government information on the Internet and on their confidence in searching the Internet for government information. 
Usefulness. Usefulness was measured by asking the trainees to rate on a fivepoint scale ( 1 being least useful and 5 being most useful) the usefulness of seven parts of the program, namely, industry statistics, demographic data, economic conditions, current regulations, pending and recent legislation, sources of assistance, and hands-on practice.

Effects related to searching government Web sites. On a five-point scale (1 being strongly disagree and 5 being strongly agree), trainees indicated whether the training improved their Internet searching skills, enhanced their confidence in searching government Web sites, and increased their knowledge of government information on the Internet.

Other training effects. On a five-point scale ( 1 being strongly disagree and 5 being strongly agree), trainees were asked to indicate whether more training programs on similar topics should be offered to small business users in the future and whether the trainees would search government Web sites more often in the future.

It is by no means easy to balance research and library service, but there seems to be great potential for academic librarians to integrate the two.

\section{Results}

Analysis of the pretraining assessment showed that 81.8 percent of the trainees had Internet access. Approximately 52 percent were unaware that the government will publish most of its information in electronic format; one-third did not know that much of government information could be found on the Internet; and 50 percent did not know that special assistance in locating government information was available in federal depository libraries in their community. Seventy percent never or rarely searched the Internet for government information. About half of the attendees expressed little confidence in searching government Web sites $(53.3 \%)$ and nongovernment Web sites (48.4\%).
Analysis of the posttraining assessment showed that of the subject areas of the program, hands-on practice, sources of assistance, and demographic data were rated the top three most useful areas to their business. Most of the trainees agreed or strongly agreed that the training increased their knowledge of government information on the Internet $(87.1 \%)$, improved their Internet search skills for government information $(83.9 \%)$, and enhanced their confidence in searching for government information on the Internet $(90.3 \%)$.

The posttraining assessment confirmed that the program achieved its primary goals of encouraging and enabling small business users to use government information on the Internet. It exposed the trainees to a wide range of government sources available on the federal government Web sites. The trainees learned some basic Internet search skills, became more familiar with the different formats and structures of government information published on the Internet, and became more aware of the federal depository libraries in New Jersey, where they could obtain assistance in searching for government information. Most important, the training increased their confidence in conducting an Internet search for government information. Ninety percent of the trainees indicated that more training programs on the topic should be offered to small business people in the future, and 87.1 percent said they would search government Web sites more frequently.

\section{Discussion and Conclusion}

In an endeavor to serve the government information needs of small businesses, the authors learned to integrate research and service in a complementary and synergistic way. The research questions regarding small business executives' awareness and use of government information arose from a commitment to high-quality service to the small business community in an era of information technology. Research findings, in turn, shed light on the problems 
the authors faced and laid the conceptual foundations for designing and implementing the training program. Evaluating the program provided feedback to previous research, stimulated new research questions, and provided experience that can be applied to future user service programs. Research and service thus created a synergistic cycle in which they stimulated and provided input to each other that resulted in not only research publications, but also needed user services.

It is worth pointing out that the authors' integrative model requires the librarians' active engagement in the process. Librarians have to utilize research findings and service experience to generate support and resources from relevant parties. For instance, one has to "sell" issues with important practical implications to research bodies and research findings to service providers for gathering resources and support.

The academic and service environment of an organization is important to the integration of research and service. The aforementioned librarian engagement presupposes the existence of potential support. In the authors' case, they received guidance and support from professors of entrepreneurship at the Rutgers Center for Entrepreneurial Management, who commented on the survey questionnaires, allowed their students to do pilot testing, and provided financial support. ${ }^{12}$ On the service side, the authors had support from the New Jersey
Small Business Development Center located on the campus. Academic librarians should be aware of the potentials and limitations and conscientiously cultivate relationships with potential collaborators.

This experience taught the authors that research-guided outreach programs are most effective in bringing recognition and opportunities and in connecting the authors with both academic faculty and client community. The entrepreneurship program of the Faculty of Management has since invited the authors to participate in their curriculum development, and the SBDC has expressed interest in cosponsoring future programs with the library.

The integrative method that worked effectively in this study might be due to individual and institutional characteristics specific to the authors' personal experiences. Each academic librarian who desires to balance research and service needs to find his or her own way of integrating the two components. It is by no means easy to balance research and library service, but there seems to be great potential for academic librarians to integrate the two. To the extent that such integration is successful, it will improve the productivity and quality of both research and service, which will, in turn, contribute to creating knowledge in librarianship, providing high-quality service to users, enhancing the relationship with the community, and advancing the career of individual librarians.

\section{Notes}

1. W. Bede Mitchell and L. Stanislava Swieszowski, "Publication Requirements and Tenure Approval Rates: An Issue for Academic Librarians," College \& Research Libraries 46 (May 1985): $249-55$.

2. Robert Boice, Jordan M. Scepanski, and Wayne Wilson, "Librarians and Faculty Members: Coping with Pressures to Publish," College E Research Libraries 48 (Nov. 1987): 494-503; William K. Black and Joan M. Leysen, "Scholarship and the Academic Librarian," College \& Research Libraries 55 (May 1994): 229-41; Donald E. Riggs, "Faculty Status for Librarians: Force-Fitting into an Inappropriate Mold or Not?" College \& Research Libraries 60 (July 1999): 305-6.

3. Black and Leysen, "Scholarship and the Academic Librarian," 230.

4. Willis Bridegam, "A Research Requirement for Librarians?" Journal of Academic Librarianship 4 (July 1978): 135-36.

5. Black and Leysen, "Scholarship and the Academic Librarian," 229-41.

6. Ibid., 230. 
7. Ann C. Weller, Julie M. Hurd, and Stephen E. Wiberley Jr., "Publication Patterns of U.S. Academic Librarians from 1993 to 1997," College \& Research Libraries 60 (July 1999): 352-62.

8. Black and Leysen, "Scholarship and the Academic Librarian," 231.

9. Wen-Hua Ren, “U.S. Government Information Need, Awareness, and Searching: A Study of Small Business Executives," Journal of Government Information 26, no. 5 (Oct. 1999): 453-65; "Self-Efficacy and the Search for Government Information: A Study of Small Business Executives," Reference E User Services Quarterly 38, no. 3 (spring 1999): 283-91.

10. The authors would like to thank all those who helped in the program. Special acknowledgment is extended to Lynn Mullins, director of the Dana Library, and Theo Haynes, business librarian of Robeson Library, Rutgers-Camden, for their support and assistance.

11. The Web page entitled Uncle Sam to the Rescue! Searching for Government Information on the Web is available online at http://newarkwww.rutgers.edu/guides/unclesam.htm.

12. Gratitude is extended especially to Dr. Patricia Greene, former professor in the Faculty of Management of Rutgers University, for her guidance and assistance. 